\title{
The Case for State Mandatory Assignment of BENEFITS LEGISLATION
}

\author{
Elliott McKinnis*
}

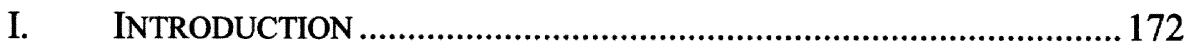

II. BACKGROUND: HISTORY OF HEALTH CARE PLANS AND AOB ......173

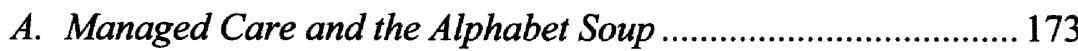

B. The Development of Managed Care Plans ............................... 175

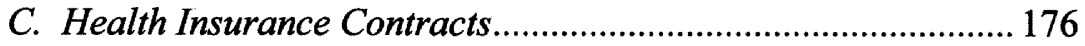

D. Legal Challenges to Anti-Assignment Provisions..................... 177

E. AOB Laws around the Country............................................... 178

1. Overview of AOB Laws Around the Country....................... 178

2. Florida's Recent AOB Law............................................ 179

3. Indiana's Efforts to Pass an AOB Law................................ 180

III. ARGUMENTS IN FAVOR OF STATES MANDATED AOB ..................... 181

A. Mandatory AOB Would Provide Fairness to Providers ............ 181

B. Mandatory AOB Would Eliminate Many Administrative Problems Associated with Payments and Billing...................... 183

C. Mandatory $A O B$ Would Reduce the Amount of Litigation between Insurers and Providers ............................................... 184

D. Mandatory AOB Would Reduce the Amount of Out-of-Network Providers Who Require Full Payment

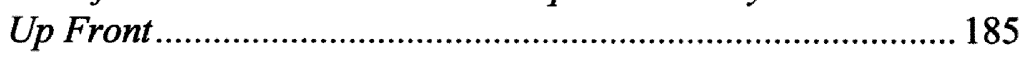

IV. ARGUMENTS AGAINST STATES MANDATING AOB ........................186

A. Mandatory AOB Would Weaken Insurers' Health Care

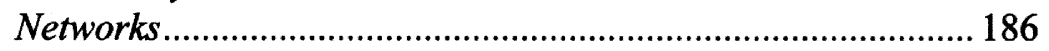

B. Mandatory AOB Would Increase Health Care Costs ................ 187

C. Mandatory $A O B$ Would Interfere with an Insurer's Ability to Manage Quality of Care......................................................... 189

V. WHY THE ARGUMENTS IN FAVOR OF MANDATORY AOB PREVAIL AND HOW LEGISLATION SHOULD BE STRUCTURED......... 190 A. Why Indiana Should Mandate AOB ......................................... 190

1. How the Refusal of Insurers to Honor AOB Harms the Health Care System........................................................ 190

2. The Evidence Fails to Show That Mandatory $A O B$ Weaken Networks.

3. The Evidence Fails to Show That Mandatory AOB Increases Health Care Costs Generally................................ 192

B. Structure of the Legislation....................................................... 193

1. Indiana Legislators Should Consider a Conditional

* J.D., 2010, Indiana University School of Law-Indianapolis; B.A., 2002, Ball State University. 
Sunset Provision.

2. Indiana Legislators Should Consider Imposing

Requirements on Reimbursement Amount

3. Indiana Legislators Should Consider Prohibiting Out-of-Network Providers from Balance Billing.

4. Indiana Legislators Should Consider Repealing the State's AWP Law.

VI. CONCLUSION 197

\section{INTRODUCTION}

After visiting a non-network urologist, a Virginia woman's insurer sent her a check to cover a portion of the expenses incurred. Around the same time she received the check, her son's college tuition also came due. The woman used the money from her health insurance check to pay the university. She still owed her urologist, however, and when the urologist tried to collect from her sometime later, he was unable to do so because she had declared bankruptcy. ${ }^{1}$ This story is not unique. In fact, some doctors say it occurs often enough that it threatens their ability to provide health care services. ${ }^{2}$ A potential solution is to require insurance companies to honor an individual's wish to send payments directly to her provider, even if the provider is not in the insurer's network. In other words, an individual should have the power to assign her benefits to an out-of-network provider.

Some states have passed mandatory assignment of benefits ("AOB") legislation. ${ }^{3}$ A mandatory AOB law requires insurers to send payments directly to out-of-network providers who have executed an AOB agreement with the covered individual. Proponents of mandatory AOB legislation suggest there are other important advantages to AOB beyond making it eas-

1. Tammie Smith, Va. Doctors Make Their Case They Are Lobbying Legislators For Changes in How Benefits, Reimbursements Are Handled, RicHMOND TimEs DisPATCH, Jan. 24,2005 , at A1.

2. See, e.g., id, Smith supra note 1.

3. See Ala. Code $\S 27-1-19$ (2010); Alaska Stat. $\S 21.51 .120$ (2010); Cal. HEALTH \& SAFETY CODE $§ 1371.4$ (Deering 2010); ColO. REV. STAT. $\$ 10-16-317.5$ (2010); CONN. GeN. STAT. 38A-472 (2010); FLA. STAT. § 627.638 (2009); GA. CODE ANN. § 33-24-54 (2010); IdAHo Code ANN. § 34-3417(3) (2010); 215 Ill. Comp. Stat. ANN. 5/370a (LexisNexis 2010); LA. Rev. Stat. ANN. § 40:2010 (2010); ME. Rev. Stat. ANN. tit. 24, § 2332-H (2010); Mo. Rev. Stat. § 376.427 (2010); Nev. ReV. STAT. ANN. § 689A.135 (LexisNexis 2010); N.H. REv. STAT. ANN. § 420-B:8-n (LexisNexis 2010); N.C. GeN. STAT. § 58-3-225 (2010); OHo ReV. CODE ANN. § 3901.386 (LexisNexis 2008); R.I. GeN. LAWS § 27-18-63 (2010); S.D. CoDIFIED LAWS § 58-17-61 (2010); TENN. CODE ANN. § 56-7-120 (2010); TeX. INS. CODE ANN. $\S 1204.053$ (West 2009); VA. CODE ANN. $§ 38.2-3407.13$ (2010); Wyo. STAT. ANN. § 26-15-136 (2010); see also OR. REv. STAT. § 743-531 (2009) (allowing but not requiring insurers to honor AOB); WASH. REV. CODE $\S 48.44 .026$ (West 2010) (generally requiring the signature of the out-of-network provider in order to deposit a check from an insurer). 
ier for health care providers to collect payments. ${ }^{4}$ However, critics contend that mandatory AOB would have negative effects on the health care system. ${ }^{5}$ Section II of this note presents background information on the history of the AOB issue. Section III examines the arguments in favor of mandatory AOB legislation, and Section IV explores the arguments against mandatory AOB. Finally, Section V explains why the arguments in favor of mandatory AOB prevail and how Indiana should structure mandatory AOB legislation.

\section{BACKGROUND: History OF HEALTH CARE PLANS AND AOB}

A brief history of the development of the health care industry provides a helpful basis on which to analyze the AOB issue. The most basic reason for the existence of health insurance plans is that people want to share the risk of financial loss due to illness or injury. ${ }^{6}$ A health insurance plan generally includes four parties: consumers, providers, sponsors, and intermediaries. $^{7}$ Consumers, often referred to as "insureds," "patients" and "subscribers," are those who receive care from providers. ${ }^{8}$ Sponsors include employers who offer a group health benefit plan to their employees and pay a majority of the plan's expenses. ${ }^{9}$ In the case of Medicare and Medicaid, the government plays the role of sponsor. ${ }^{10}$ Intermediaries provide an administrative framework, which includes the bill paying process (i.e., payers, insurers, health plans, etc.). ${ }^{11}$

\section{A. Managed Care and the Alphabet Soup}

Many health plans today fall under the label of "managed care.", Definitions of managed care vary. ${ }^{13}$ However, a common definition describes it as a system that attempts to control health care cost, access, and

4. See, e.g., Steven R. West, Fla. Med. Ass'n President, Op-Ed., More Choices, Access Needed for Patients, SUN SENTINEL (Fort Lauderdale), June 4, 2009, at 12A.

5. See, e.g., Catherine Dolinski, Gaetz Says Health Bill Is Good for Workers, TAMPA TRIBUNE, May 22, 2009, at 10.

6. Peter R. Kongstvedt, Managed Care: What It Is and How It Works 21 (3rd ed. 2009); Jonathan P. Weiner \& Gregory de Lissovoy, Razing a Tower of Babel: A Taxonomy for Managed Care and Health Insurance Plans, 18 J. HEALTH POL. POL'Y \& L. 75, 81 (1993).

7. Weiner \& de Lissovoy, supra note 6 , at $80-81$.

8. Id.

9. Id. at 80 .

10. Id. at $80-81$.

11. Id. at 81 .

12. See generally KONGSTVEDT, supra note 6, at 17-53 (describes the types of managed care plans in existence today); William N. Tindall ET AL., A Guide to MANAGED CARE MED. 8-14 (2000) (describes the types of managed care plans in existence today).

13. KONGSTVEDT, supra note 6, at 230. 
quality. ${ }^{14}$ Defining the separate classes of managed care health plans is also a difficult task. ${ }^{15}$ Some analysts describe the health care system as an "unintelligible alphabet soup of three-letter health plans."16 Examples of the three-letter health plans include health maintenance organizations ("HMOs"), preferred provider organizations ("PPOs"), and point-of-service plans ("POSs"). 17

At one time, the individual models included unique features that distinguished them from each other. ${ }^{18}$ HMOs, in their purest form, involve prepaid arrangements where the payer offers subscribers health care services in exchange for a monthly fee. ${ }^{19}$ HMO models attempt to control health utilization and quality more than other plans. ${ }^{20}$ HMOs are designed to include a primary care physician who operates as a gatekeeper by overseeing the patient's care and providing referrals to specialists. ${ }^{21}$ Except under limited circumstances, a subscriber is responsible for the total health care costs when visiting a provider outside of the $\mathrm{HMO}^{22}$

The PPO design involves less control of health care cost and quality than HMO plans, but generally gives the patient more freedom in choosing providers. ${ }^{23}$ PPOs contain a network of physicians who bill for each service at a discounted rate. ${ }^{24}$ A subscriber may have a deductible, which is a fixed out-of-pocket amount the consumer is required to pay before the health plan will cover any fees. ${ }^{25}$ After the deductible is met, the subscriber then may pay a coinsurance amount, which is a small percentage of each service he receives. ${ }^{26}$

Some providers, specialists in particular, are often outside of PPO networks. $^{27}$ If the patient wants to use an out-of-network provider, the health plan will reimburse the subscriber, usually at a rate that is reduced by a difference of twenty percent. ${ }^{28}$ For example, if a health plan pays eighty

14. See id.

15. Id. at 17.

16. Weiner \& de Lissovoy, supra note 6 , at 75.

17. See generally KONGSTVEDT, supra note 6, at 17-53; TINDALL ET AL., supra note 12, at 8-14; Carol K. Lucas \& Michelle A. Williams, The Rights of Nonparticipating Providers in a Managed Care World: Navigating the Minefields of Balance Billing and Reasonable and Customary Payments, 3 J. HEALTH \& LIFE SCI. L. 132, 135 (2009).

18. See KonGSTVEDT, supra note 6, at 17-18.

19. Id. at 226.

20. Id at 32 .

21. Lucas \& Williams, supra note 17 , at 135.

22. KONGSTVEDT, supra note 6, at 32.

23. See id. at 30-31; see also Lucas \& Williams, supra note 17, at 135.

24. KongSTVEDT, supra note 6, at 30-31.

25. Id.

26. Id. at 30-31, 213.

27. Mandated Health Benefit Task Force, Report of the Mandated Benefit TASK FORCE 5 (2008), available at http://www.in.gov/legislative/igareports/agency/ reports/IDOI37.pdf.

28. KONGSTVEDT, supra note 6, at 31 . 
percent of the cost of a certain service offered by an in-network provider, the plan would pay sixty percent for that same service when offered by an out-of-network provider. ${ }^{29}$

A POS plan is a hybrid of plans similar to HMOs and PPOs. ${ }^{30}$ POS plans operate similar to HMOs when the consumer follows HMO procedures. ${ }^{31}$ When the subscriber wants to use an out-of-network provider, the POS operates more like a PPO. ${ }^{32}$

\section{B. The Development of Managed Care Plans}

Researchers assert that managed care originated in 1910, when a group of providers in Washington began offering a broad range of services to Tacoma lumber mill workers for a monthly premium of $\$ 0.50$ per member. ${ }^{33}$ This concept evolved during the Great Depression when physician groups and hospitals established health plans to maintain or increase patient revenue. ${ }^{34}$ By World War II, employers began creating HMOs as a benefit for employees and other consumers demanding greater access to less expensive health care. ${ }^{35}$

In the 1960 s, the cost of health care skyrocketed. ${ }^{36}$ In an effort to support the development of more private sector health plans, Congress passed the HMO Assistance Act of $1973 .^{37}$ Meanwhile, in the 1970s the health care system saw the creation of PPOs. ${ }^{38}$ Despite this growth in managed care, by 1980 approximately ninety percent of employed Americans received health coverage from indemnity insurance. ${ }^{39}$ However, in the $1980 \mathrm{~s}$ traditional indemnity plans began to decline, while the prevalence of HMOs and other managed care entities grew. ${ }^{40}$ By 1990 , indemnity plans covered

29. See generally Peter R. Kongstvedt, Compensation of Primary Care Physicians in Managed Health Care, in THE MANAGED HeAlTH CARE HANDBOOK 132 (Peter R. Kongstvedt ed., 4th ed. 2001) (describing out-of-network fees). 135.

30. KonGSTVEDT, supra note 6, at 31-32; see also Lucas \& Williams, supra note 17, at

31. KongSTVEDT, supra note 6, at 31-32.

32. Id. at 31 .

33. Id. at 1; see also TINDALL ET AL., supra note 12, at 4-6 (describing the evolution of managed care).

34. KONGSTVEDT, supra note 6, at 2.

35. Id. at 2-3.

36. TINDALL ET AL., supra note 12, at 5.

37. Health Maintenance Organization Act of 1973, Pub. L. No. 93-222, 87 Stat. 914 (codified as amended at 42 U.S.C. $\S \S 300 \mathrm{e}-300 \mathrm{e}-17$ (2010)); see also KONGSTVEDT, supra note 6, at 2; TINDALL ET AL., supra note 12, at 5.

38. KONGSTVEDT, supra note 6 , at 6.

39. Weiner \& de Lissovoy, supra note 6, at 76. See generally KoNGSTVEDT, supra note 6 , at 29 (noting that indemnity plans traditionally did not include networks and made little or no attempt to control health care costs).

40. KONGSTVEDT, supra note 6, at 9 (stating that "[i]n the mid-1980s, HMOs grew fastest, but by the early 1990s, PPOs began to grow even faster"); see also Weiner \& de Lissovoy, supra note 6, at 77 ("By the end of the 1980s traditional insurance plans and estab- 
less than half of all Americans. ${ }^{41}$

Another spike in health care costs over the past decade led to an increase in the consumer's responsibility to pay for care. ${ }^{42}$ Today, the distinctions among the numerous types of health care plans have been blurred. ${ }^{43}$ Plans identified as HMOs, for example, are adopting some characteristics of PPOs and vice versa. ${ }^{44}$

\section{Health Insurance Contracts}

Regardless of the label used, the health insurance industry utilizes contracts as the basis for the rights and responsibilities that one party owes another. ${ }^{45}$ The features of the contract include agreements on the services a plan provides, the process consumers must use to access those services, and the manner of reimbursement. ${ }^{46}$ Contracts that include networks generally require the payers to reimburse the in-network providers directly for the services that those providers render to their patients who are consumers under the plan. ${ }^{47}$ However, an insurance company has no contractual obligation to directly reimburse out-of-network providers because those providers do not share a contractual relationship with the plan. ${ }^{48}$ Even though contracts specify duties, laws, and regulations, courts also govern the relationships among the parties. ${ }^{49}$

A modern view of courts interpreting contracts is that parties generally can assign, or in other words transfer, their contractual rights to a third party. ${ }^{50}$ Receiving health insurance benefits is a right a policyholder has from a contract with the insurer, assuming that the policyholder does not violate any of the terms. ${ }^{51}$ Therefore, under this modern approach to contract law, a covered individual could transfer the right to health insurance benefits to a

lished HMOs were joined by a stunning array of new health care financing and delivery entities.").

41. Weiner \& de Lissovoy, supra note 6, at 77 (citing Elizabeth W. Hoy et al., Change and Growth in Managed Care, 10 HeAlTH AFF. 18 (1991)).

42. KONGSTVEDT, supra note 6 , at 15.

43. Id. at 17-18; see also Weiner \& de Lissovoy, supra note 6, at 75 ("There is little agreement about which characteristics distinguished one type of plan from another.").

44. KONGSTVEDT, supra note 6, at 10-11.

45. Lucas \& Williams, supra note 17 , at 136; see also Weiner \& de Lissovoy, supra note 6 , at 81 .

46. Lucas \& Williams, supra note 17 , at $136-37$.

47. See KONGSTVEDT, supra note 6 , at 29.

48. Lawrence Foust, $A$ Proposal for Resolving Differences in Managed Care Contract Negotiations Between Providers and Payers, in Health LaW HandBook § 3:3 (Alice G. Gosfield ed., 2006).

49. Lucas \& Williams, supra note 17 , at 137.

50. Somerset Orthopedic Assocs., P.A. v. Horizon Blue Cross and Blue Shield of N.J., 785 A.2d 457, 460 (N.J. Sup. Ct. App. Div. 2001) (citing Rumbin v. Utica Mut. Ins. Co., 757 A.2d 526, 531 (Conn. 2000)); see also RESTATEMENT (SECOND) OF CONTRACTS $\$ 317 \mathrm{cmt}$. c (1981) (stating that "the historic common-law rule that a chose of action could not be assigned has largely disappeared.").

51. See Lucas \& Williams, supra note 17 , at $136-37$. 
third party, such as an out-of-network provider. Under this scheme, the insurer would send reimbursement directly to the out-of-network provider.

\section{Legal Challenges to Anti-Assignment Provisions}

Before the last decade, insurers in Indiana generally allowed policyholders to assign benefits to out-of-network providers. ${ }^{52}$ Currently, some health plans have contractual provisions with policyholders that prohibit the covered individual from assigning benefits to out-of-network providers. ${ }^{53}$ Courts usually do not allow parties to assign their rights when the contract includes provisions that explicitly prohibit assignment. ${ }^{54}$ When consumers have challenged prohibitions on assignment, courts have generally upheld the provision by reasoning that assigning benefits is against public policy. ${ }^{55}$ Nonetheless, there is at least one outlier decision in which the court used public policy considerations to actually require an insurer to honor $\mathrm{AOB}{ }^{56}$

52. Interview with Michael Rinebold, Dir. of Gov't Relations, Ind. State Med. Ass'n, in Indianapolis, Ind. (Nov. 24, 2009) [hereinafter Interview with Rinebold]; see also, e.g., Letter from Stacey Breidenstein, Director, Provider Contracting \& Institutional Relations, CareFirst BlueChoice, Inc., to Providers (Aug. 8, 2005), available at http://www.bmbassoc.com/issues/aob/docs/BCBS_2008\%20CareFirst\%20Reimbursement\% 20 for $\% 20$ Non-Par\%20Svcs.pdf (explaining that the insurer would stop sending reimbursements directly to out-of-network providers).

53. Interview with Rinebold, supra note 52; see, e.g., Parrish v. Rocky Mountain Hosp. \& Med. Servs. Co., 754 P.2d 1180, 1181-82 (Colo. Ct. App. 1988) (quoting a Blue Cross Blue Shield ("BCBS") of Colorado contract provision that read: "All benefits stated in the Contract are personal to the Employee or Dependent. Neither those benefits nor [BCBS] of Colorado's payments to the covered individual may be assigned to any person, corporation or entity: Any attempted assignment shall be void. The only exception to this provision is [BCBS] of Colorado's right to pay Participating Facility and Professional Providers directly."); see also KONGSTVEDT, supra note 6, at 2.

54. Somerset Orthopedic Assocs., 785 A.2d at 460 (citing Owen v. CAN Insurance/Continental Cas. Co., 771 A.2d 1208, 1213-14 (N.J. 2001)); see RESTATEMENT (SECOND) OF CONTRACTS $\S 317(2)$ ("A contractual right can be assigned unless . . . assignment is validly precluded by contract.").

55. See, e.g., St. Francis Reg'l Med. Ctr. v. Blue Cross Blue Shield of Kan. Inc., 810 F. Supp. 1209 (D. Kan. 1992), aff'd, 49 F.3d 1460 (10th Cir. 1995); Parrish, 754 P.2d at 1182 ("[N]on-assignment clauses in this type of contract are valuable tools in persuading health providers to keep their health care costs down . . . ."); Kent General Hosp., Inc. v. Blue Cross and Blue Shield of Del., Inc., 442 A.2d 1368 (Del. 1982); Augusta Med. Complex, Inc. v. Blue Cross of Kan., Inc., 634 P.2d 1123 (Kan. 1981); ObstetriciansGynecologists, P.C. v. Blue Cross and Blue Shield of Neb., 361 N.W.2d 550 (Neb. 1985); Somerset Orthopedic Assocs., 785 A.2d at 464 ("[T] tool to [the insurer's] efficient and effective functioning . . . ."); Kassab v. Med. Serv. Ass'n. of Pa., Inc., $39 \mathrm{~Pa}$. D. \& C.2d 723, 725 (1966) (holding that the anti-assignment clause was valid and essential to the continued success of the insurer's plan), aff'd per curiam, $230 \mathrm{~A} .2 \mathrm{~d}$ 205 (Pa. 1967); see infra Part IV (discussing why courts have found assignment of benefits to out-of-network providers against public policy).

56. Am. Med. Int'l, Inc. v. Ark. Blue Cross and Blue Shield, 773 S.W.2d 831, 832 (Ark. 1989) (noting that an insured has an "interest in freely assigning the right to payment . ...."); see also St. Francis Reg'1 Med. Ctr., v. Blue Cross and Blue Shield of Kan., 49 F.3d 1460, 1468-70 (10th Cir. 1995) (Ebel, J., dissenting) (explaining that the district court's de- 


\section{E. AOB Laws around the Country}

\section{Overview of $A O B$ Laws Around the Country}

Because the position of the majority of courts is to enforce antiassignment provisions when they exist in health insurance contracts, some states have enacted laws to force insurers to accept a patient's request for AOB. ${ }^{57}$ As of January, 2010, approximately two dozen states had enacted mandatory AOB laws. ${ }^{58}$ Approximately half of those states have AOB laws that cover many types of providers. ${ }^{59}$ The AOB laws of the remaining states only apply to certain categories like dental or emergency care. ${ }^{60}$

Further, some people who participate in the AOB debate believe that whether a state has an Any-Willing-Provider ("AWP") law is relevant to the question of whether AOB legislation is appropriate. ${ }^{61}$ AWP laws require insurers to accept into their networks any provider that meets the general standards set by the insurer. ${ }^{62}$ Nearly half of the states in the nation have AWP laws, most of which are limited to dental and pharmacy services. ${ }^{63}$ Fewer than ten states apply their AWP laws to health care providers beyond dental services. ${ }^{64}$ Indiana's AWP law, for example, establishes that "[n]o hospital, physician, pharmacist, or other provider . . . willing to meet the terms and conditions of [a network agreement] may be denied the right to enter into a [network]."

cision to dismiss the hospital's claim that BCBS of Kansas's nonassignability clause violates public policy should be reversed).

57. Foust, supra note 48.

58. See supra note 48; see also AM. DeNTAL Ass'N, AssignMENT OF BENEFITs (2010), available at $\mathrm{http}: / / \mathrm{www}$. ada.org/sections/advocacy/pdfs/thirdparty_assignment_benefits.pdf; MANDATED HEALTH BENEFIT TASK FORCE, supra note 27, at 4.

59. MANDATED HEALTH BENEFIT TASK FORCE, supra note 27, at 2 (states with broad AOB laws as of July 2008, are Alabama, Alaska, Colorado, Georgia, Illinois, Maine, Missouri, Nevada, Tennessee and Texas); see also AM. MED. Ass'N, MODEL AssignMENT OF BENEFITS LEGIS. (2004), available at http://www.bmbassoc.com/issues/aob/docs/AMA_2004-AOB\%20model\%20legislation.pdf.

60. MANDATED HEALTH BENEFIT TASK FORCE, supra note 27, at 3 (states with limited AOB laws as of July 2008, are Connecticut, Idaho, Louisiana, Massachusetts, Ohio, Rhode Island, South Dakota, Wyoming and Virginia). See, e.g., OHIO REV. CODE ANN. § 3901.386 (LexisNexis 2008) (applying only to "hospital services provided on an emergency basis"); R.I. GEN. LAwS § 27-18-63 (2010) (applying only to dental care providers).

61. See infra Part V.B.4.

62. MANDATED HEALTH BENEFIT TASK FORCE, supra note 27, at 3; see, e.g., IND. CODE ANN. § 27-8-11-3 (West 2003). See generally Richard I. Smith \& Kristin Stewart, State Regulation of Managed Care, in The Managed Health CARE HaNdBoOK 1332, 1334-5 (Peter R. Kongstvedt ed., 4th ed. 2001) (describing state regulatory structures for managed care organizations).

63. MANDATED HeAlTh BENEFIT TASK ForCE, supra note 27, at 4; see, e.g., IND. CODE ANN. § 27-8-11-3 (West 2003).

64. MANDATED HEALTH BENEFIT TASK FORCE, supra note 27, at 4.

65. IND. CODE ANN. § 27-8-11-3(c) (West 2003); see also VA. CODE ANN. § 38.2-3407 (2008) ("No hospital, physician or a type of provider [as defined by a separate statute] willing to meet the terms and conditions offered to it or him shall be excluded [from a net- 
States have many different combinations of AOB and AWP laws. ${ }^{66}$ Some states have a broad AOB law and a limited AWP law or vice versa. ${ }^{67}$ However, only Georgia has both a broadly applied AOB law and a broadly applied AWP law. ${ }^{68}$

\section{Florida's Recent $A O B$ Law}

In 2009, Florida joined the ranks of states with mandatory AOB. ${ }^{69}$ Despite strong opposition from Blue Cross Blue Shield ("BCBS") of Florida and from consumer groups, the Florida Legislature passed a mandatory AOB bill. ${ }^{70}$ The bill, which took effect July 1, 2009, amended Florida's statutes to require mandatory AOB to all providers. ${ }^{71}$ Florida's AOB statute now reads as follows:

Whenever, in any health insurance claim form, an insured specifically authorizes payment of benefits directly to any recognized hospital, licensed ambulance provider, physician, dentist, or other person who provided the services in accordance with the provisions of the policy, the insurer shall make such payment to the designated provider of such services. The insurance contract may not prohibit, and claims forms must provide an option for, the payment of benefits directly to a licensed hospital, licensed ambulance provider, physician, dentist, or other person who provided the services in accordance with the provisions of the policy for care provided. The insurer may require written attestation of assignment of benefits.

work].").

66. MANDATED HEALTH BENEFIT TASK ForCE, supra note 27, at 4.

67. Id.

68. Id.; see, e.g., Ga. Code Ann. § 33-24-54 (requiring insurers that pay benefits directly to network providers to also pay benefits directly to: "any similarly licensed nonparticipating or nonpreferred provider who has rendered such services, has a written assignment of benefits, and has caused written notice of such assignment to be given to the person licensed under this title or jointly to such nonparticipating or nonpreferred provider and to the insured, subscriber, or other covered person; provided, however, that in either case the person licensed under this title shall be required to send such benefit payments directly to the provider who has the written assignment. "); GA. CODE ANN. § 33-20-16 (2006) (requiring "[e]very doctor of medicine, every doctor of dental surgery, every podiatrist, and every health care provider within a class approved by the health care corporation who is appropriately licensed to practice and who is reputable and in good standing shall have the right to become a participating physician or approved health care provider for medical or surgical care, or both, as the case may be, under such terms or conditions as are imposed on other participating physicians or approved health care providers within such approved class under similar circumstances in accordance with this chapter.").

69. See 2009 Fla. Laws. 2009-124 (codified at FLA. STAT. § 627.638 (2009)).

70. Dolinski, supra note 5.

71. FLA. STAT. § 627.638(2) (2009). 
Payment to the provider from the insurer may not be more than the amount that the insurer would otherwise have paid without the assignment. ${ }^{72}$

\section{Indiana's Efforts to Pass an AOB Law}

Between 2005 and 2010, Indiana legislators worked to enact broadly applied, mandatory AOB legislation. ${ }^{73}$ As of the end of the 2010 session, the furthest point an AOB bill reached in the legislative process in Indiana was a vote in the chamber where it originated. ${ }^{74}$ In February, 2009, twentyfive members of the Indiana Senate voted in favor of a mandatory AOB bill, twenty-four members voted against it, and one member was excused from the vote. ${ }^{75}$ Even though the bill received more votes in its favor, it failed because it lacked a constitutional majority. ${ }^{76}$ The bill would have required insurers to send benefit payments directly to all out-of-network providers when the provider and the consumer have an assignment of benefits agreement. ${ }^{77}$

Legislators have continued their efforts beyond the 2009 session. ${ }^{78}$ In the 2010 session, three senators introduced a bill similar to those introduced in previous years that would require broadly applied, mandatory $\mathrm{AOB} .^{79}$ However, this Senate bill was never voted on during the short legislative session. $^{80}$

In addition to working on $A O B$ legislation during sessions of the Indiana General Assembly, state lawmakers and an independent state government commission have analyzed the issue between sessions. ${ }^{81}$ In October

72. Id.

73. Telephone Interview with Patricia Miller, Ind. State Senator, Ind. State Senate, in Indianapolis, Ind. (Dec. 10, 2009).

74. See S.B. 75, 116th Gen. Assemb., 1st Reg. Sess. (Ind. 2009), available at $\mathrm{http}: / / \mathrm{www}$.in.gov/apps/1sa/session/billwatch/billinfo?year=2009\&session=1\&request=getBi $11 \&$ docno $=0075 \&$ doctype $=$ SB.

75. Roll Call Vote on S.B. 75, IND. GEN. ASSEM., http://www.in.gov/legislative/bills 12009/PDF/Srollcal/0168.PDF.pdf (last visited Sep. 7, 2010).

76. See Ind. Const. art. IV, $\S 25$ (requiring a majority of the Senate's fifty members to pass a bill in the Indiana Senate).

77. S.B. 75, 116th Gen. Assemb., 1st Reg. Sess. (Ind. 2009), available at $\mathrm{http} / / \mathrm{www}$. in.gov/apps/lsa/session/billwatch/billinfo?year $=2009$ \&session=1\&request=getBi $11 \&$ docno=0075\&doctype=SB. See generally IND. CODE § 27-8-11-1 (2009) (defining provider as "an individual or entity duly licensed or legally authorized to provide health care services.").

78. See S.B. 326, 116th Gen. Assemb., 2d Reg. Sess. (Ind. 2010), available at $\mathrm{http}: / / \mathrm{www}$.in.gov/apps/1sa/session/billwatch/billinfo?year=2010\&session=1\&request=getBi $11 \&$ docno $=326$ ).

79. See id.

80. See id.

81. See generally MANDATEd HeAlth BeNEFT TASK ForCe, supra note 27; IND. HeAlth Fin. COMm'N, InTERIM STUdy COMmittee MeEting Minutes OF SEP. 1, 3-4 (2009), available at $\mathrm{http}: / / \mathrm{www}$.in.gov/legislative/interim/committee/minutes/HFCOC91.pdf. 
2008, the Mandated Benefits Task Force ${ }^{82}$ issued findings and recommendations regarding AOB proposals. ${ }^{83}$ The report suggested that a mandatory AOB law in Indiana should only apply to situations where health care consumers "have no choice in the selection of provider." ${ }^{84}$ As the report elaborated, those situations could include providers who are emergency room physicians, anesthesiologists, radiologists, or pathologists. ${ }^{85}$ The task force further recommended that a mandatory AOB law may need to include provisions to protect consumers from receiving a bill for unreimbursed services after their providers receive payment directly from their insurers. ${ }^{86}$

\section{ARGUMENTS IN FAVOR OF STATES MANDATED AOB}

As the Indiana General Assembly and other state legislatures debate the issue of whether to require insurers to honor AOB agreements, many different interest groups have visited statehouses around the country. ${ }^{87}$ The primary proponents of broadly applied, mandatory AOB legislation include different groups of providers. ${ }^{88}$ For example, representatives from the Indiana State Medical Association ("ISMA") and from individual associations of chiropractors, psychologists, and dentists have appeared before state lawmakers in Indiana to present their case as to why the state should have a mandatory AOB law. ${ }^{89}$

\section{A. Mandatory AOB Would Provide Fairness to Providers}

Proponents of mandatory AOB legislation argue it would provide fairness to providers by ensuring that they would receive compensation for the services they offer. ${ }^{90}$ The Indiana Psychological Association ("IPA") says denying patients the right to assign benefits to their out-of-network providers "often prevents the Psychologist's [sic] office from ever receiving payment." ${ }^{\text {"91 }}$ An association of Maryland medical group administrators conducted a survey revealing that eighty-four percent of respondents indicated that patients frequently fail to pay their medical bills after receiving

82. The governor appoints a ten-member task force with representatives from insurance companies, consumers, health care providers, employers, and independent actuaries. IND. CODE ANN. § 27-1-3-30 (West 2003).

83. See MANDATED HEALTH BENEFIT TASK ForCE, supra note 27.

84. Id. at 5 .

85. Id.

86. Id.

87. See, e.g., Dolinski, supra note 5; IND. HEALTH Fin. CoMM'N, supra note 81, at 3-4.

88. See, e.g., IND. HEAlTH FIN. COMM'N, supra note 81, at 3-4.

89. See, e.g., id at 4.

90. Id.

91. IND. PSYChOL. Ass'N, AOB Position PAPER (2009) (on file with Ind. Legis. Servs. Agency and with author). 
reimbursements. ${ }^{92}$

The IPA explains that when patients receive reimbursement from their insurer, they often think that they no longer have a debt to their health care provider. ${ }^{93}$ Meanwhile, the patients may use the reimbursements to cover other outstanding debts like a child's college tuition, resulting in an inability to pay their medical provider. ${ }^{94}$ Some medical group administrators and doctors note that collection problems involving patients who have received reimbursements are becoming an increasingly common occurrence. ${ }^{95}$

Also, these situations are not limited to people who use their reimbursement checks for reasons as noble as paying a child's college tuition bill. ${ }^{96}$ In a newspaper opinion piece, the chief executive officer of a Florida addiction-treatment program described the story of a man whose health insurance company sent him a reimbursement check. ${ }^{97}$ The man, who had received treatment for a drug addiction, did not pay his provider, but rather used the money to buy drugs off the street. ${ }^{98}$ The executive also described another man who received reimbursement of more than $\$ 1,000$ and used it to take a trip, where he committed suicide. ${ }^{99}$

Regardless of the reasons why patients fail to pay their providers after receiving a reimbursement check, the result is that at least some providers accumulate a significant amount of charges that must be written off as a loss and re-classified as an expense because it is unable to be collected (i.e., bad debt). ${ }^{100}$ The Indiana Dental Association ("IDA") compiled anecdotal data to show how collection issues are affecting providers. ${ }^{101}$ A survey of dentist offices in central and northern Indiana showed that each accumulat-

92. Letter from Kem Tolliver, Gov't Affairs Chair, Md. Med. Grp. Mgmt. Ass'n, to Thomas Middleton, State Senator, Comm. Chairman, Md. S. Fin. Comm. (Mar. 17, 2009) [hereinafter Letter from Tolliver], available at http://www.bmbassoc.com/ issues/aob/docs/MD_2009\%20MGMA\%20Letter\%20to\%20Middleton.pdf.

93. IND. PSYCHOL. Ass'N, supra note 91.

94. Smith, supra note 1.

95. Hearing on S.B. 852 before the Senate Finance Committee, 2010 Leg., 426th Sess. (Md. 1999) (written testimony of the Hosp. Based Physician Coal. in support of S.B. 852), available at http://www.bmbassoc.com/issues/aob/docs/ MD_2009\%20SB\%20852\%20AOB\%20Testimony.pdf; Letter from Tolliver, supra note 92 ("With the current state of our economy, it is highly improbable that the patient would turn over the payment to pay the provider for their services.").

96. See IND. HEALTH FIN. COMM'N, supra note 81, at 3 (representative of the Indiana Dental Association stating states generally that people do not always have noble reasons for their alternative uses of their reimbursement checks).

97. Chris Crosby, The Watershed Addiction Treatment Programs President, Op-Ed., Paying Mental Health Facilities Directly Saves Lives, PALM BeACH Post, June 2, 2009, at 8 A.

98. Id.

99. Id.

100. See IND. DENTAL Ass'N, 2008/2009 AOB EXPERIENCE (on file with Ind. Legis. Servs. Agency and with author).

101. See id. 
ed $\$ 8,000$ to $\$ 13,000$ of bad debt in six months, ${ }^{102}$ or roughly ten percent of the revenues an average dentist office would receive after overhead expenses are subtracted. ${ }^{103}$ One dentist stated that his billing staff spends forty percent of its time trying to locate money from patients who have received reimbursement from their insurers but have yet to pay their debt with their dentist. $^{104}$ Providers who experience collection problems may incur bad debt and subsequently raise rates. ${ }^{105}$

Proponents further argue that insurers may deny AOB as a way to force providers into a network that has low reimbursement rates. ${ }^{106}$ Some providers say allowing health insurance companies to reject $A O B$ presents them with the undesirable choice of either entering a network and accepting lower reimbursement rates or staying outside the network and chasing payments that the insurer sends to their patients. ${ }^{107}$ Therefore, some providers suggest that using the direct payment incentive as leverage is an unfair business practice. ${ }^{108}$ Some doctors say this is especially unfair in the current health insurance system because providers have a decreasing amount of bargaining power in negotiations with health plans. ${ }^{109}$ While insurance companies acknowledge that direct payments are used to attract providers to their networks, they argue that the direct payment incentive is justified because it helps them build or maintain strong networks, which leads to a reduction of health care costs. ${ }^{110}$

\section{B. Mandatory AOB Would Eliminate Many Administrative Problems Associated with Payments and Billing}

AOB proponents also assert that the process of insurers reimbursing patients for out-of-network medical services is cumbersome without

102. Id.

103. Interview with Ed Popcheff, Director of Gov't Relations, Ind. Dental Ass'n, in Indianapolis, Ind. (Dec. 10, 2009).

104. IND. DENTAL Ass'N, supra note 100.

105. See IND. HeALTH FIN. Comm'N, supra note 81, at 3; see also Smith, supra note 1 (quoting an internist who said that "[y]ou can't run a practice with thousands of dollars not coming in.").

106. IND. HEALTH FIN. COMM'N, supra note 81, at 3; see also Lucas \& Williams, supra note 17, at 143; IND. PSYCHOL. Ass'N, supra note 91 ("Some insurers pressure Psychologists [sic] into signing their PPO contract by refusing to honor assignment of benefits for nonPPO patients.").

107. IND. HEALTH FIN. COMM'N, supra note 81, at 3.

108. See, e.g., id. (stating that rejecting AOB to force dentist to join networks is "simply wrong").

109. Smith, supra note 1 (describing the struggles some providers have during negotiations with health plans); AM. MED. Ass'N, AOB LEGISLATION TALKING POINTs (2004), available at http://www.bmbassoc.com/issues/aob/docs/AMA_2004- AOB\%20Talking\%20 Pionts.pdf (describing that the "playing field" is becoming more unbalanced in favor of the insurers over the providers).

110. See infra Part. IV.A-B. 
AOB. ${ }^{111}$ The IPA says that barring an individual from assigning benefits to a provider "disrupts payments to the Psychologist's [sic] office [and] creates confusion ...."112 The IPA explains that the provider's office may not be informed that the patient received compensation, which could cause weeks of delay in the billing process. ${ }^{113}$ This confusion, caused by the inability to assign benefits, may be compounded when the patient has coverage by more than one insurer. ${ }^{114}$ Finally, the IPA asserts that in some cases involving dual coverage, these administrative complications result in a patient failing to receive all of the benefits to which he or she is entitled. ${ }^{115}$

There is also concern that the effects of administrative billing difficulties may discourage patients from visiting out-of-network providers, and thereby decrease patient access. ${ }^{116}$ The IDA contends that AOB would eliminate many of the administrative problems associated with payments and billing. ${ }^{117}$ Even if a provider eventually receives payment, some note that the provider might experience delays and cash flow disruptions if it cannot receive payments directly from the insurer. ${ }^{118}$ Some say that these delays harm patients because they reduce the time that providers can spend focusing on actual health care. ${ }^{119}$

\section{Mandatory AOB Would Reduce the Amount of Litigation between Insurers and Providers}

It is also argued that mandatory AOB laws would provide efficiency, consistency, and predictability. ${ }^{120}$ Many times when there are issues re-

111. InD. HeAlth FIn. ComM'N, supra note 81, at 3; see also Mark R. Stetzel \& Bob Ketcham, Dentists Split about States Benefit Bill: Pro, Journal J. GaZeTTE (Fort Wayne, Ind.), Jan. 30, 2009, at 13A ("For patients not expecting an insurance check, it's confusing when it arrives in the mail ... . For those who do forward the check to their dentist, it's just another hassle they don't need.'); AM. MED. Ass'N, supra note 109.

112. IND. PSYCHOL. Ass'N, supra note 91.

113. Id.

114. Id. ("If the patient is covered by more than one insurance company or by Medicaid (dual coverage) the Psychologist [sic] cannot file for secondary benefits on behalf of the patient until an explanation of benefits (EOB) is received from the first carrier.").

115. Id.

116. Diane D. Anderson, Healthcare Consultants, LlC, AOB Legis. For HeAlTHCARE PROVIDERS 7 (2005), available at http://www.bmbassoc.com/issues/aob /docs/FINALReport.doc (prepared for Virginians for Fairness in Healthcare).

117. InD. HEALTH FIN. COMM'N, supra note 81, at 3 (A representative of the Indiana Dental Association states that "the current process is a hassle to the patient and intrusive on administering a dental practice.”); see also MD. GEN. ASSEM. DEP'T OF LEGIS. SERVS., H.B. 594 FISCAL AND POL'Y NOTE 1 (2010), available at http://mlis.state.md.us/2010rs/fnotes/ bil_0004/hb0594.pdf.

118. Karin Bierstein, Rejecting a Bad Payer Contract, AM. Soc'Y OF ANESTHESIOLOGISTS NEWSLETTER, June 2005, available at http://www.asahq.org/ Newsletters/2005/06_05/pracMgmt06_05.html.

119. Seé, e.g., Steven West, supra note 4.

120. Foust, supra note 48. 
garding payments between insurers and out-of-network providers, the end result is litigation. $^{121}$ This creates significant transactional costs. ${ }^{122}$ The ISMA fears that those transactional costs may negatively affect the cost of health care in general. ${ }^{123}$ The ISMA states that health care providers do not want to play the role of creditor, but they are often forced to do so. ${ }^{124}$ Proponents think that allowing AOB would help remove the need for providers to go to court after patients fail to pay, because when the patient assigns the benefits, the insurer's reimbursement goes directly to the provider. ${ }^{125}$

Furthermore, when an insured is unable to assign benefits to an out-ofnetwork provider, the provider generally cannot challenge the insurer's reimbursement $^{126}$ The American Medical Association says that providers are more willing and capable of investigating and appealing the reimbursements when a dispute exists concerning the amount the health plan should cover. $^{127}$ Therefore, the organization says that it is unfair to give patients the responsibility of legally challenging a reimbursement. ${ }^{128}$

\section{Mandatory $A O B$ Would Reduce the Amount of Out-of-Network Provid- ers Who Require Full Payment Up Front}

Proponents argue that AOB would reduce the number of out-ofnetwork providers who require full payment before services are rendered because they know they will receive some reimbursement from an insurer. $^{129}$ For example, many Indiana psychologists have begun to ask for upfront payments because of the difficulty of collecting payments after they provide services. ${ }^{130}$ Many dentists who do not participate in a network are also forced to choose whether to require up-front payments or risk that the

121. Id.

122. Id.

123. Interview with Rinebold, supra note 52.

124. Id.

125. Id.

126. David M. Hyman et al., Hey, What About Me? Non-Participating Healthcare Providers' Ability to Sue Health Insurance Companies Regarding Payment of Claims, N.J. LAWYER, February 2007, at 37 ("Without a valid assignment, non-participating providers face a considerable hurdle in establishing the right to demand or contest payment from health insurance companies.").

127. AM. MED. Ass'N, supra note 109.

128. Id.

129. See Dolinski, supra note 5; AM. MED. Ass'N, supra note 109 ("If an assignment is given by the patient and ignored by the insurer, the patient is forced to 'front' the cost of the service, until the insurer either sends payment to the patient or the provider reimburses the patient. This is an unreasonable burden to place on the consumer.").

130. Ind. HeAlth Fin. CoMm'N, supra note 81, at 3; see also IND. Psychol. Ass'N, supra note 91 ("[AOB] often allows patients to leave the office without making full payment for services, knowing that the psychologists will bill them for any balance not paid by the insurance company."). 
patient will not pay later. ${ }^{131}$ Because of this, the IDA argues that AOB would lead to "little or no up-front costs at the time of treatment." "132

\section{ARguments Against States MANDATING AOB}

\section{A. Mandatory AOB Would Weaken Insurers' Health Care Networks}

As proponents of mandatory AOB present their arguments to state lawmakers, health insurance companies, employers, and labor unions join forces to argue their opposing positions. ${ }^{133}$ A chief argument against enacting broadly applied, mandatory AOB is that it would weaken insurers' health care networks. ${ }^{134}$ Insurance companies contend that a doctor's ability to receive reimbursements directly from an insurer is an important incentive for the physician to join the insurer's network. ${ }^{135}$ The argument is that if any provider can receive direct payments from any insurer, then there is less of an incentive to stay in a certain network. ${ }^{136}$

During AOB legislative debates in Maryland, an insurer presented evidence regarding the effect AOB had on other health plans. ${ }^{137}$ The Maryland-based insurer, CareFirst BCBS, reported that when Idaho enacted mandatory AOB in 1992, half of the dentists in one network dropped out of it within a matter of weeks. ${ }^{138}$ CareFirst also noted that a survey of Hawaiian providers indicated that slightly more than half would leave a network if insurers were required to honor AOB. ${ }^{139}$ CareFirst also presented data that

131. Ind. HeAlTh Fin. Comm'N, supra note 81, at 3.

132. Support Patient Rights - Support Assignment of Benefits, IND. DENTAL Ass'N, http://www.supportpatientrights.com (last visited Dec. 7, 2010).

133. See, e.g., IND. HEALTH FIN. COMM'N, supra note 81, at 3-4; Dolinski, supra note 5; Smith, supra note 1 .

134. See Lucas \& Williams, supra note 17, at 143-44; VA. DEP'T OF PlanNING AND BUDGET, H.B. 253 FISCAL IMPACT STATEMENT 1 (2006), available at http://leg1.state.va.us/cgi-bin/legp504.exe?071+oth+HB253F122+PDF; JOHN M. WANDER \& DANIEl Freier, RENDEN \& ANDERs, LTD., The Potential IMPaCt of State Mandatory ASSIGNMENT LEGIS. ON CONSUMERS 10 (2003), available at http://www.bcbsok.com/grassroots/pdf/bcbsa_assignmentofbenefitsrpt_oct03.pdf (prepared for BCBS Ass'n); Smith, supra note 1; IND. HEALTH Fin. COMM'N, supra note 81, at 3-4.

135. FLA. S., S.B. 1122 ANALYSIS AND FISCAL IMPACT STATEMENT 4 (2009), available at http://www.flsenate.gov/data/session/2009/Senate/bills/analysis/pdf/2009s1122.ga.pdf; see also Dolinski, supra note 5; MANDATED HEALTH BENEFIT TASK FORCE, supra note 27, at 4 ("Direct payment of claims to participating providers is a key benefit of contracting with a health care payer."); Letter from William Casey, V.P. Gov't Affairs, CareFirst BCBS, to Thomas Middleton, State Senator, Md. S. Fin. Comm. 1 (Mar. 4, 2009) [hereinafter Letter from Casey], available at http://www.bmbassoc.com/issues /aob/docs/BCBS_2009\%20Letter\%20to\%20Middleton\%20SB\%20852.pdf.

136. Smith, supra note 1.

137. Letter from Casey, supra note 135 , at 3.

138. Id.

139. Id. (The source does not state whether this survey was scientific). 
a Virginia insurer had a stronger network after adopting a policy to refuse AOB. ${ }^{140}$ It was further mentioned by CareFirst that insurers in Nevada and Colorado have experienced difficulty in establishing strong networks because of mandatory AOB legislation. ${ }^{141}$ Advocates for the health industry argue that a weakened network would result in less access to care for patients because there would be fewer providers participating in a network. ${ }^{142}$

\section{B. Mandatory AOB Would Increase Health Care Costs}

In addition to decreased access to health care services, many argue that weakened networks would generally result in higher health care costs. ${ }^{143}$ During the AOB debate in the Virginia General Assembly in 2006, a representative of a health insurance company explained to a journalist that "[h]ealth plan networks are all that stand between consumers and full charges." 144 Health insurance industry representatives say that networks exist so insurers can negotiate rates with providers in an effort to contain or reduce the amount of money consumers pay out of their pockets for health care services. ${ }^{145}$ A provider would agree to this lower rate in exchange for a higher volume of patients. ${ }^{146}$ Health insurance representatives say that the agreement of in-network doctors to provide services at a discounted rate "substantially reduces health-care premiums." 147

The BCBS Association commissioned a study in 2003 that showed discounts and protections that patients receive from using networks for their care amount to thousands of dollars for people with major medical conditions. ${ }^{148}$ The study looked at five patient "profiles,",149 and found estimated annual cost savings of $\$ 3,234$ to $\$ 13,482$ for in-network physician services and $\$ 6,751$ to $\$ 30,404$ for in-network hospital services. ${ }^{150}$ The study con-

140. Id.

141. Id. Nevada first enacted an AOB law in 1983, and Colorado did the same in 2005 . MANDATED HEALTH BENEFIT TASK FORCE, supra note 27, at 2.

142. Bob Lotane, Commc'ns and Pol. Affairs Dir., Nat'l Ass'n of Ins. Fin. Advisors, Op-Ed., Direct Assignment Bill Guts Preferred Provider Plans, PALM BEACH Post, June 4, 2009 , at $12 \mathrm{~A}$.

143. See Jed Jacobson, V.P. of Delta Dental of Ind., Guest Commentary, Assignment of Benefits Hits Patients in Pocketbooks, THE TIMES OF NORTHWEST IND., Jan. 29, 2009; Cyrus Jollivette, Senior V.P. of Public Affairs, BCBS of Fla., Op-Ed., SB 1122 Will Undermine PPO Networks, Raise Health-care Costs, PALM BEACH Post, June 11, 2009, at 10A; IND. HEALTH FIN. COMM'N, supra note 81, at 3.

144. Smith, supra note 1.

145. WANDER \& FREIER, supra note 134.

146. Smith, supra note 1.

147. Lotane, supra note 142.

148. See WANDER \& FREIER, supra note 134.

149. See id. at 7-8 (noting the five profiles as, "woman with advanced breast cancer," "man with coronary artery heart disease," "child with severe asthma," "woman with ischemic stroke," "man with diabetes mellitus").

150. Id. at 10. 
cluded that savings like these might be reduced if networks were weakened as a result of mandatory $\mathrm{AOB} .{ }^{151}$ Some argue that even if doctors do not leave their networks, $A O B$ to out-of-network providers may give network doctors more leverage in their negotiations with insurers to argue for higher reimbursements. ${ }^{152}$ This leverage could interfere with the insurer's ability to negotiate with network providers for a lower reimbursement rate and thus could translate to higher medical costs for consumers. ${ }^{153}$

According to the insurer, CareFirst, AOB legislation in Idaho in 1992 resulted in a twenty-nine percent increase in out-of-pocket health care costs. ${ }^{154}$ CareFirst estimates that for every ten-percent loss in provider participation in its network, the health care costs for consumers would increase by eight percent. ${ }^{155}$ The health insurance industry further argues that the deterioration of their PPO networks would increase the number of uninsured citizens. ${ }^{156}$

Some employers and labor unions fear that weakened networks would translate to higher premiums. ${ }^{157}$ Employers are worried that by weakening health care networks, mandatory AOB would interfere with an insurer and an employer negotiating a contract. ${ }^{158}$ Legislative staff in Virginia who analyzed the issue came to the conclusion that weakened health care networks would lead to higher premiums for both employers and their employees. ${ }^{159}$

When Florida considered passing a mandatory AOB bill in 2009, BCBS of Florida asserted that a mandatory AOB would impose a significant cost to Florida's State Employees' Health Insurance Trust Fund because of the effect of a weakened network. ${ }^{160}$ A BCBS of Florida analysis showed that it would cost the trust fund between $\$ 9.9$ million and \$25.7 million in one fiscal year. ${ }^{161}$ Florida's Department of Management Services contracted out a study to review BCBS of Florida's analysis of how much mandatory AOB would cost the state. That study showed a range of $\$ 5.1$

151. Id.

152. Dolinski, supra note 5.

153. See FLA. S., supra note 139.

154. Letter from Casey, supra note 135 , at 3.

155. Id. at 2 .

156. Jollivette, supra note 143.

157. See, e.g., IND. HeAlth Fin. COMm'N, InTERIM Study Committee MeEting MINUTES OF SEP. 1, Exhibit 7, 3 (2009) ("[Mandatory AOB legislation would] have a very significant impact on increasing the cost of health care and forcing even more employers to discontinue providing coverage.") (on file with Ind. Legis. Servs. Agency and with author); IND. HEALTH FIN. COMM'N, supra note 81, at 4 (AFL-CIO representative stating that strong networks result in millions of dollars worth of savings and "direct payments to out-ofnetwork providers would increase costs").

158. IND. HEALTH FIN. COMM'N, supra note 81, at 4.

159. VA. DEP'T OF PLANNING AND BUDGET, supra note 134.

160. Fla. S., supra note 135; see also VA. DEP'T OF PLANNING AND BUDGET, supra note 134.

161. FLA. S., supra note 135. 
million to $\$ 18.5$ million. ${ }^{162}$ The state's independent study also showed that mandatory AOB would increase an individual's out-of-pocket expenses by seventy-five percent. ${ }^{163}$

\section{Mandatory $A O B$ Would Interfere with an Insurer's Ability to Manage Quality of Care}

In addition to managing the cost of health care, insurers attempt to control the quality of care. ${ }^{164}$ Some believe that conferring the right to collect directly from insurers would blur the distinction between network providers and out-of-network providers, which could be harmful to the system. ${ }^{165}$ For good or bad, networks play a central role in the benefit design of our health care system. ${ }^{166}$ The ability to collect reimbursements directly from insurers is often only available to providers who are in the health plan's network. ${ }^{167}$ However, the method of receiving reimbursements for services is not the only distinction between network providers and out-of-network providers. Among the many important differences are quality assurance and credentialing. ${ }^{168}$ Therefore, some argue that blurring the distinction between network providers and out-of-network providers would harm the insurance companies' ability to create what they think is the most "intelligent, legally acceptable, and commercially attractive" benefit design. ${ }^{169}$ Furthermore, insurers argue that mandatory AOB would result in providers exiting their networks. ${ }^{170}$ If this occurs, the health insurance companies would not be able to manage the quality of health care as effectively because the network would have fewer participating providers. ${ }^{171}$ Also, insurers may not be able to offer some specialized services like chronic care management because of a lack of participating providers. ${ }^{172}$

162. Id. (citing GABRIEl RoEDER SMITH \& Co., REVIEW OF MANDATORY ASSIGNMENT MODEL (2009)).

163. Id.

164. See KongSTVEDT, supra note 6, at 230.

165. Foust, supra note 48.

166. Id.

167. See KongSTVEDT, supra note 6, at 139.

168. Foust, supra note 48.

169. Id; see also, e.g., Letter from Casey, supra note 135, at 3 ("CareFirst, like other carriers, continually strives to improve the quality of our networks.").

170. Letter from Casey, supra note 135, at 3.

171. Id.

172. Id. 
V. WHY THE ARGUMENTS IN FAVOR OF MANDATORY AOB PREVAIL AND HOW LEGISLATION SHOULD BE STRUCTURED

\section{A. Why Indiana Should Mandate $A O B$}

The parties who participate in the AOB debate have in large part tried to present their arguments within the frame of what is best for consumers. ${ }^{173}$ However, both insurance companies and doctors have interests in making profits. One possible solution falls somewhere between the positions of providers, insurers, and sponsors. Indiana legislators should require that health plans honor AOB, as well as create a conditional sunset provision for the AOB legislation. The legislature should also consider imposing requirements on the amount of reimbursement paid to out-of-network providers, prohibiting balance billing for emergency care services, and repealing the state's AWP law.

\section{How the Refusal of Insurers to Honor AOB Harms the Health Care System}

Considering that anecdotal data dominates the AOB debate, legislators likely have a difficult time weighing the potential outcomes of their decision regarding the AOB issue. ${ }^{174}$ At least in Indiana, opponents of mandatory $\mathrm{AOB}$ note that proponents do not use empirical data to support their arguments. ${ }^{175}$ For example, the testimonies of Indiana providers detail the experience of only some medical offices. ${ }^{176}$ Nonetheless, these testimonies show that the inability of at least some out-of-network doctors to receive direct reimbursements poses significant financial burdens on their practices. ${ }^{177}$ Assuming that these providers will shift at least some of the financial burden to patients, it follows that the insurers' refusal to honor AOB raises the cost of care that these out-of-network doctors provide. ${ }^{178}$

The evidence also shows that some consumers covered by a network plan choose to receive services from out-of-network providers at least some of the time. ${ }^{179}$ When the insureds are unable to assign their health insurance benefits to their out-of-network providers, they often experience a cumbersome process of waiting to receive payments from the health plan and paying their doctor's bills. ${ }^{180}$ The evidence further shows that the insurer's

173. See, e.g., id. at 4.

174. See IND. HEALTH FIN. COMM'N, supra note 81, at 3-4.

175. See id. at 3.

176. See id. at $3-4$.

177. See id.

178. See generally supra Part III.A.

179. IND. HEALTH FIN. COMM'N, supra note 81, at 3-4.

180. See generally supra Part III.B. 
refusal to honor assignment requests increases the transactional costs of health care delivery, as doctors spend more time trying to collect payment from patients and patients have more disputes with their health plans regarding reimbursements. ${ }^{181}$ Furthermore, the refusal to honor AOB requires some providers to demand up-front payments from consumers because of the uncertainties of being able to collect from them. ${ }^{182}$ These additional consequences that result from an insurer's refusal to honor AOB further raise or at least threaten to raise the cost of receiving services from out-ofnetwork providers. These consequences also likely affect, to some degree, access to care from out-of-network providers. ${ }^{183}$

\section{The Evidence Fails to Show That Mandatory AOB Weaken Networks}

While the evidence shows that allowing insurers to prohibit AOB increases the cost of health care that some out-of-network doctors provide, the health insurance industry argues that a mandatory AOB law would create a net increase in health care costs. ${ }^{184}$ However, information presented by health insurance companies does not prove such a position. ${ }^{185}$ In AOB discussions, insurers primarily argue that $A O B$ laws threaten the strength of their networks. ${ }^{186}$

For example, when the Maryland General Assembly considered an AOB bill in 2009, an insurer, CareFirst, presented data in an effort to show the effect of AOB laws on the strength of health plan networks. ${ }^{187}$ As discussed more fully in Section IV, CareFirst's information included anecdotal data about Idaho dentists from 1992, a survey of Hawaii providers, the effect of a Virginia insurer's anti-assignment policy on its own network, and general statements about the strength of the networks of insurers from $\mathrm{Ne}$ vada and Colorado. ${ }^{188}$ While this evidence supports the argument that $\mathrm{AOB}$ laws may weaken health plan networks, it provides an insufficient basis to conclude that this result would happen in Indiana if the legislature enacted mandatory AOB.

181. See generally supra Part III.C.

182. See generally supra Part III.D.

183. See ANDERSON, supra note 116, at 7.

184. See, e.g., IND. HEALTH FIN. COMM'N, supra note 81, at 3-4.

185. See MGT of Am., Inc., Research ConCERning Premium Rate Changes for the FLA. MED. Ass'N 7 (2008) (on file with author) (finding that "[ $t]$ he direct impact of incorporating mandatory assignment of benefits and/or a reduction of the repayment period on health insurance premiums cannot be determined").

186. See, e.g., IND. HEALTH FIN. COMM'N, supra note 81, at 3-4; See generally supra Part IV.A.

187. Letter from Casey, supra note 135, at 3-4. But cf. Letter from Tolliver, supra note 92 (stating that a survey of Maryland providers shows that ninety-percent would remain innetwork even if legislature would enact AOB law).

188. Letter from Casey, supra note 135, at 3-4; see also supra Part IV.A. 
In 2005, a consulting group that studied the AOB issue for a Virginia group of doctors concluded that AOB laws had not interfered with insurers' ability to provide "adequate cost-effective networks."189 The consultants observed that three of the four main health insurance companies in the United States - United Healthcare, Aetna, and Cigna - honor AOB but have not incurred any negative financial consequences for doing so. ${ }^{190}$ According to some reports, the insurance company, Humana, also honors AOB while containing costs with a "strong" network. ${ }^{191}$ The evidence that several insurers voluntarily allow AOB and maintain strong networks indicates AOB laws would likely have minimal effect on the strength of health plan networks. Other incentives, such as higher patient volume, will likely keep a large number of doctors in network, even if they can receive direct payments out of network. ${ }^{192}$

Even if the networks of insurers would weaken in the coming years, the decline of strong networks would not necessarily be a result of mandatory AOB. "An increasing number of physicians do not contract with managed care companies."193 Some providers believe a major reason for doctors leaving networks is because insurers' reimbursement rates are too low regardless of whether there is AOB. ${ }^{194}$

\section{The Evidence Fails to Show That Mandatory AOB Increases Health Care Costs Generally}

Even assuming that $\mathrm{AOB}$ laws weaken networks, health insurance companies have failed to prove the resulting weak networks would cause a net harm by increasing costs or limiting access to health care. As discussed previously, health insurance representatives commonly testify to the amount of health care savings members receive for participating in a.plan that uses a network. ${ }^{195}$ For example, representatives often cite a 2003 study that a consulting group completed for the BCBS Association. ${ }^{196}$ This study tracked the savings that some types of patients realized when they used innetwork doctors. ${ }^{197}$ In at least one AOB debate, an insurer asserted that outof-pocket costs of consumers covered by a network increased by an esti-

189. ANDERSON, supra note 116, at 28.

190. Id.

191. Dolinski, supra note 5; West, supra note 4.

192. Dolinski, supra note 5.

193. Hyman et al., supra note 126.

194. E.g., Smith, supra note 1. But cf., e.g., Letter from Casey, supra note 135, at 3 (explaining that the insurers' rates are "fair and reasonable"). IV.B.

195. See, e.g., InD. HEALth Fin. COMM'N, supra note 81, at 3-4; see also supra Part

196. See WANDER \& FREIER, supra note 134.

197. Id. 
mated twenty-nine percent in Idaho in 1992 because of AOB legislation. ${ }^{198}$

Despite empirical evidence showing savings consumers realize for using network doctors, and anecdotal data like the experience of Idaho patients, no one has established a correlation between AOB and an overall increase of health care costs. ${ }^{199}$ Even assuming that mandatory AOB laws increase health care costs for some consumers, health insurance companies have failed to show this would cause a net increase in total costs. Furthermore, the evidence does not show that the increase in costs insurers fear would outweigh the financial burdens that out-of-network providers incur because of their inability to receive direct reimbursements.

The extent of the harm that out-of-network providers in Indiana experience because insurers refuse to honor AOB is unknown. Nonetheless, evidence shows that allowing payers to reimburse consumers directly increases the cost of out-of-network services, assuming that out-of-network doctors share some of their financial burdens with their patients. Meanwhile, AOB opponents base their arguments on speculation, which does not show that mandatory AOB would create a net harm to health care costs. Therefore, Indiana should enact a broadly based, mandatory AOB law.

\section{B. Structure of the Legislation}

\section{Indiana Legislators Should Consider a Conditional Sunset Provision}

When Florida implemented a broadly applied, mandatory AOB, it included a conditional sunset provision. ${ }^{200}$ The amendment to Florida's AOB law are automatically repealed three years after its effective date if the Office of Program Policy Analysis and Government Accountability finds that "the amendments made by this act have caused the third-party administrator of the state group health plan to suffer a net loss of physicians from its preferred provider plan network and, as a direct result, caused an increase in costs to the state group health plan."201 Indiana has entertained a similar

198. Letter from Casey, supra note 135, at 2 (stating that "member out of pocket costs increased by an estimated $29 \%$ as a direct result of the passage of assignment of benefits legislation").

199. See ANDERSON, supra note 116, at 28.

200. 2009 Fla. Laws. 2009-124 (codified at FlA. STAT. $\$ 627.638$ (2009)); see also About OPPAGA, OfFICE OF PROGRAM POLICY ANALYSIS AND Gov'T ACCOUNTABILITY, http://www.oppaga.state.fl.us/shell.aspx?pagepath=about/about.htm (last visited Dec. 7, 2010) (The Florida OPPAGA is a staff unit of the Legislature responsible for examining agencies and programs "to improve services and cut costs when directed by state law, the presiding officers, or the Joint Legislative Auditing Committee." OPPAGA supports the Florida Legislature by providing data, evaluative research, and objective analyses that assist legislative budget and policy deliberations.)

201. 2009 Fla. Laws. 2009-124 (codified at FLA. STAT. $§ 627.638$ (2009)) 
mechanism in its debate over imposing a mandatory AOB. ${ }^{202}$ A conditional sunset provision could be a good tool to help protect the health care system in Indiana if the insurance companies' worst fears were to occur because of AOB legislation.

\section{Indiana Legislators Should Consider Imposing Requirements on Reimbursement Amount}

Requiring insurers to send payments directly to out-of-network providers could result in "wasteful disputes" over the amount of reimbursements. $^{203}$ However, state legislators could create a more predictable business environment by imposing requirements on the reimbursement amount for out-of-network payments. ${ }^{204}$ Only a limited number of states have enacted legislation that governs the amount insurers pay to out-ofnetwork providers. ${ }^{205}$

Florida's mandatory AOB law, for example, prohibits insurers from paying providers more than what the insurer would pay the insured if there were no assignment. $^{206}$ If an insurer in Oklahoma pays a provider less than what the provider billed, the payer must furnish, upon request, the rationale for the reimbursement amount. ${ }^{207}$ In Utah, payers must reimburse out-ofnetwork doctors at an amount that is at least seventy-five percent of the participating provider rate. ${ }^{208}$ Colorado insurers must reimburse out-ofnetwork providers the lesser of the following amounts: the provider's billed charges; a "negotiated rate"; and the "the greater of the carrier's average innetwork rate for the relevant geographic area or the usual, customary, and reasonable rate for such geographic area."209 Meanwhile, California's regulations require insurers to pay out-of-network providers the "reasonable and customary value for the health care services," which is calculated based on the following:

(1) the provider's training, qualifications, and length of time in practice; (ii) the nature of the services provided; (iii) the fees usually charged by the provider;

202. IND. HEALTH Fin. COMM'N, supra note 81, at 4.

203. Foust, supra note 48.

204. Id.

205. Id. See generally Kongstvedt, supra note 29, at 132 (describing the method insurers generally use to reimburse out-of-network providers).

206. FLA. STAT. §627.638(2) (2009) ("Payment to the provider from the insurer may not be more than the amount that the insurer would otherwise have paid without the assignment.").

207. OKLA. STAT. ANN. tit. $36 \S 6571$ (West 2009).

208. UTAH CODE ANN. § 31A-22-617(2)(b) (2009).

209. Colo. ReV. STAT. $\S 10-16-704(2)$ (c) (2007). The statute defines the "usual, customary, and reasonable rate" as "a rate established pursuant to an appropriate methodology that is based on generally accepted industry standards and practices." $\S 10-16-704(2)(f)(I I I)$. 
(iv) prevailing provider rates charged in the general geographic area in which the services were rendered;

(v) other aspects of the economics of the medical provider's practice that are relevant; and (vi) any unusual circumstances in the case. ${ }^{210}$

Although there is no consensus among the states on how to govern out-ofnetwork reimbursements, these examples provide guidance on how the Indiana General Assembly should control the reimbursement amount if or when it enacts a mandatory $\mathrm{AOB}$ law.

\section{Indiana Legislators Should Consider Prohibiting Out-of-Network Providers from Balance Billing}

Indiana legislators may also want to consider implementing a prohibition on balance billing in some situations as a compliment to AOB legislation. Balance billing occurs when a provider bills a patient for the cost that exceeds the amount that the insurer covers. ${ }^{211}$ Most states do not explicitly prohibit balance billing and insurers rarely can prohibit out-of-network providers from engaging in the billing practice. ${ }^{212}$ However, some states restrict out-of-network providers from balance billing. ${ }^{213}$ For example, New York providers cannot balance bill patients for emergency ambulance services. ${ }^{214}$ Meanwhile, Maryland and Florida prohibit providers from balance billing any HMO member. ${ }^{215}$

The Indiana Mandated Benefits Task Force in its analysis of the AOB issue in 2008 recommended the state legislature to consider providing pro-

210. CAL. CODE REGS. tit. $28, \S 1300.71$ (a)(3)(B) (2008).

211. KONGSTVEDT, supra note 6, at 210.

212. Lucas \& Williams, supra note 17 , at 147 . See generally Foust, supra note 48 (providing a background on balance billing).

213. Lucas \& Williams, supra note 17 , at 148.

214. N.Y. INS. LAW § 3221(I)(15)(B) (McKinney 2010) (An ambulance service reimbursed pursuant to this section shall not charge or seek any reimbursement from, or have any recourse against an insured for the services provided pursuant to this paragraph, except for the collection of copayments, coinsurance or deductibles for which the insured is responsible for under the terms of the policy.).

215. FLA. STAT. $\S 641.3154(4)$ (2004)(A provider or any representative of a provider, regardless of whether the provider is under contract with the health maintenance organization, may not collect or attempt to collect money from, maintain any action at law against, or report to a credit agency a subscriber of an organization for payment of services for which the organization is liable, if the provider in good faith knows or should know that the organization is liable.); MD. CoDE ANN., HEALTH-GEN. § 19-710(p) (LexisNexis 2008)(A health care provider or any representative of a health care provider may not collect or attempt to collect from any subscriber or enrollee any money owed to the health care provider by a [HMO] ... . A health care provider or any representative of a health care provider may not maintain any action against any subscriber or enrollee to collect or attempt to collect any money owed to the health care provider by a [HMO] ....). 
tection against balance billing for emergency care services. ${ }^{216}$ The task force suggested that Indiana enact something similar to California's regulation of balance billing. ${ }^{217}$ In 2006, the California Court of Appeal held that state law did not prohibit out-of-network providers to balance bill patients for emergency services. ${ }^{218}$ The California Department of Managed Health Care subsequently created a rule that declares that balance billing of HMO members for emergency services is an "unfair billing pattern." 19

In January 2009, the California Supreme Court reversed the Court of Appeal's decision, holding that balanced billing of HMO subscribers is illegal under California law when the provider has recourse to collect from the insurer. ${ }^{220}$ As previously discussed, California's regulations require insurers to pay out-of-network providers a "reasonable and customary value for the health care services." ${ }^{221}$ The California Supreme Court analyzed the issue of balance billing by considering whom the emergency room provider should involve when he or she disputes the "reasonable and customary" amount paid by the insurer for services rendered. ${ }^{222}$ The court determined that the dispute should be between the provider and the insurer. ${ }^{223}$ In reaching its conclusion, the court explained "a patient will have little basis by which to determine whether a bill is reasonable and, because the HMO is obligated to pay the bill, no legitimate reason exists for the patient to have to do so."224

Because of the nature of emergency care services, consumers have less choice as to who provides them medical care. For example, a consumer can generally choose which doctor to visit when he has a cold but may be unable to choose the emergency room to which an ambulance will take him. A prohibition on balance billing is appropriate in a situation where the emergency-care provider requires the patient to assign benefits, and where state law mandates the insurer to honor AOB. A balance billing prohibition in this case would likely reduce "wasteful disputes."225 Therefore, Indiana legislators should consider a balance billing prohibition for emergency care services.

216. MANDATED HEALTH BENEFIT TASK ForCE, supra note 27.

217. Id.

218. Prospect Med. Grp., Inc. v. Northridge Emergency Med. Grp., 39 Cal. Rpt. 3d 456

(Cal. Ct. App. 2006), rev'd, 198 P.3d 86 (Cal. 2009).

219. CAL. CoDE REGS. tit. 28, $\$ 1300.71 .39$ (a) (2008).

220. Prospect Med. Grp., Inc., 198 P.3d at 92.

221. CAL. Code Regs. tit. 28, § 1300.71(a)(3)(B) (2008).

222. Prospect Med. Grp., Inc., 198 P.3d at 93.

223. Id.

224. Id.

225. See Foust, supra note 48 (examining topic of AOB and balance billing). 


\section{Indiana Legislators Should Consider Repealing the State's AWP Law}

Indiana legislators should consider repealing the State's AWP law when they enact a mandatory AOB statute. ${ }^{226}$ Much of the Indiana Mandated Benefits Task Force five-page report includes a chart of states comparing $\mathrm{AOB}$ and AWP laws. ${ }^{227}$ In its analysis of the AOB issue, the task force emphasized that only one state, Georgia, has a broadly based AWP law and a broadly based AOB law. ${ }^{228}$ Therefore, it is reasonable to assume that the task force considers AWP and AOB to be incompatible.

Some assert that the AWP law has "already severely damaged the ability of insurance networks to contain costs. ${ }^{229}$ As previously discussed, opponents of mandatory AOB argue that an AOB law would exacerbate the problems for an insurer to manage costs. ${ }^{230}$ Therefore, some insurers see the existence of an AWP and an AOB law as two legislative measures that negatively affect their ability to manage networks. ${ }^{231}$ However, the bulk of the evidence shows that a mandatory AOB law would not harm a payer's ability to control costs. ${ }^{232}$ Nonetheless, repealing the AWP law may be a political compromise that could help ensure the passage of a mandatory AOB law. For example, a health care policy expert at the Indiana Chamber of Commerce states that he would not oppose AOB legislation if the state would repeal its AWP law. ${ }^{233}$

\section{CONCLUSION}

The debate over whether patients should have the right to assign health insurance benefits to out-of-network providers includes interesting, yet competing, public policy arguments. This important issue has garnered the attention of state legislators around the country. ${ }^{234}$ Requiring broadly applied, mandatory AOB would likely have many advantages. Perhaps the biggest benefit is ensuring that providers receive payment for their services

226. See supra Part. II.E.1 (concerning background information on AWP).

227. MANDATED HEALTH BENEFIT TASK FORCE, supra note 27, at 2-3.

228. Id. at 4; see also GA. CODE ANN. § 33-24-54 (2008) (AOB law); GA. CODE ANN. § 33-20-16 (2008) (AWP law).

229. IND. HEALTH FIN. COMM'N, supra note 157, at 3; see also Smith \& Stewart, supra note 62, at 1334-35 (examining AWP laws and their effect on health care costs). But cf. Interview with Rinebold, supra note 52 (arguing that AWP does not harm an insurer's ability to maintain its network and health care costs because insurers can easily remove providers from their networks).

230. See generally supra Part IV.B.

231. Interview with Mike Ripley, V.P., Health Care Pol'y, Ind. Chamber of Commerce, in Indianapolis, Ind. (Nov. 20, 2009) [hereinafter Interview with Ripley].

232. See generally supra Part V.A.

233. Interview with Ripley, supra note 231.

234. See, e.g., IND. HEALTH FIN. CoMM'N, supra note 81, at 3-4. 
so they can continue to provide care without raising their rates. ${ }^{235}$ Another important advantage to mandatory AOB comes from the elimination of many of the administrative problems associated with payments and billings that providers and policyholders experience. ${ }^{236}$

However, many argue that mandatory AOB would do significant harm to the health care system. ${ }^{237}$ A principal argument is that mandatory AOB would weaken networks, which in turn would lead to higher costs for policyholders, their employers, and others. ${ }^{238}$ Nonetheless, the empirical data related to this argument is weak. ${ }^{239}$ In addition, there is evidence that mandatory AOB would do little, if anything, to weaken networks and increase health care costs overall. ${ }^{240}$ Furthermore, legislators can structure laws to help protect against any harm by including a sunset provision. ${ }^{241}$ For the foregoing reasons, Indiana should adopt a broadly applied, mandatory AOB law.

235. See generally supra Part III.A.

236. See generally supra Part III.B.

237. See, e.g., Letter from Casey, supra note 135, at 1.

238. See generally supra Part IV.A-B.

239. See supra Part V.A.

240. See ANDERSON, supra note 116, at 28.

241. See generally supra Part V.B. 